\title{
Pengaruh Pemberian Kafein Per Oral terhadap Kadar Gula Darah pada Tikus Wistar (Rattus norvegicus) Hiperglikemia
}

Ana Silvi Ni'ma ${ }^{1}$, Gadis Meinar Sari ${ }^{2}$, Lucky Prasetyowati $^{3}$

${ }^{1}$ Program Studi Pendidikan Dokter, Fakultas Kedokteran, Universitas Airlangga, Surabaya

${ }^{2}$ Departemen Ilmu Faal, Fakultas Kedokteran, Universitas Airlangga, Surabaya

${ }^{3}$ Departemen Ilmu Anatomi dan Histologi, Fakultas Kedokteran, Universitas Airlangga, Surabaya

*Corresponding author: anasilvi45@yahoo.co.id

\begin{abstract}
Background: Caffeine is a major ingredient contained in coffee that is a favorite drink of people around the world. The effect of caffeine on blood sugar levels were still unclear whether it could increase or decrease blood sugar levels. Some studies had shown that caffeine could increase blood sugar levels through its effects on decreased insulin sensitivity. On the contrary, other studies had shown that caffeine could provide a protective effect on diabetes mellitus by its effect in improving insulin sensitivity. Objective: To investigate the effects of oral caffeine on blood sugar levels in normal and hyperglycemia rats. Methods: This study used 36 rats (Rattus norvegicus) divided into 4 groups, ie hyperglycemic treated group (K1), hyperglycemic control group (K2), normal treated group (K3) and normal control group (K4). Treated groups (KI and K3) were given caffeine with a dose of $3.22 \mathrm{mg} / 200$ grams of $B B$ orally daily for 3 days. Blood glucose levels were measured before and after treatment. Data analysis used paired t-test and effect size gives significant result when $p<0.05$. Results: The results showed that oral administration of caffeine had a significant effect on blood sugar levels in normal and hyperglycemic rat. Conclusion: The effect of caffeine on blood glucose in normal and hyperglycemic rat were $81.1 \%$ and $97.7 \%$, respectively. It was concluded that oral administration of caffeine raised the blood sugar levels in normal and hyperglycemia rat.
\end{abstract}

Keywords: caffeine, blood glucose, hyperglycemia

\begin{abstract}
Abstrak
Pendahuluan: Kafein adalah zat utama yang terkandung dalam kopi yang merupakan minuman yang digemari oleh masyarakat di seluruh dunia. Pengaruh kafein terhadap kadar gula dalam darah masih belum jelas apakah dapat menaikkan atau menurunkan kadar gula darah. Beberapa penelitian membuktikan bahwa kafein dapat meningkatkan kadar gula darah melalui efeknya terhadap penurunan sensitivitas insulin. Sebaliknya, penelitian lain membuktikan bahwa kafein dapat memberikan efek perlindungan tubuh terhadap diabetes mellitus melalui pengaruhnya dalam meningkatkan sensitivitas insulin. Tujuan: Untuk mengetahui efek pemberian kafein per oral terhadap kadar gula darah pada tikus normal maupun tikus hiperglikemia. Metode: Penelitian ini menggunakan 36 tikus (Rattus norvegicus) yang dibagi menjadi 4 kelompok, yaitu kelompok tikus hiperglikemia yang diberi perlakuan (K1), kelompok tikus hiperglikemia kontrol (K2), kelompok tikus normal yang diberi perlakuan (K3) dan kelompok tikus normal kontrol (K4). Kelompok perlakuan (K1 dan K3) diberi kafein dengan dosis 3,22 mg/200 gram BB per oral setiap hari selama 3 hari. Kadar gula darah diukur sebelum dan setelah perlakuan. Analisis data menggunakan paired t-test dan effect size yang memberikan hasil signifikan apabila p < 0,05. Hasil: Hasil menunjukkan bahwa pemberian kafein secara oral memberikan efek yang signifikan terhadap kadar gula darah tikus normal dan hiperglikemia. Kesimpulan: Efek pemberian kafein terhadap kadar gula darah pada tikus normal dan hiperglikemia sebesar $81,1 \%$ dan $97,7 \%$. Sehingga dapat disimpulkan bahwa pemberian kafein per oral terhadap kadar gula darah tikus normal dan hiperglikemia dapat meningkatkan kadar gula darah pada tikus normal dan hiperglikemia.
\end{abstract}

Kata kunci: kafein, kadar gula, hiperglikemia 


\section{PENDAHULUAN}

Kafein adalah zat utama yang terkandung dalam kopi yang merupakan minuman yang digemari oleh masyarakat di seluruh dunia. Kandungan kafein pada beberapa jenis kopi adalah $95-165 \mathrm{mg}$ pada $237 \mathrm{~mL}$ kopi yang disajikan dengan cara diseduh, 47 - $64 \mathrm{mg}$ pada $30 \mathrm{~mL}$ kopi espresso, $63 \mathrm{mg}$ pada $237 \mathrm{~mL}$ kopi instan, serta 2 - $5 \mathrm{mg}$ pada $237 \mathrm{~mL}$ decaffeinated coffee (Mayo Clinic, 2018).

Efek kafein terhadap kadar gula dalam darah masih belum jelas (Urzua dkk., 2012). Terdapat penelitian yang menyatakan bahwa konsumsi kopi, yang merupakan salah satu sumber utama dari kafein dapat meningkatkan sensitivitas insulin (Arnlov, 2017), sehingga menurunkan risiko diabetes (Akash dkk., 2012; Lane dkk., 2008).

Penelitian lain menunjukkan bahwa konsumsi kafein dapat menurunkan sensitivitas insulin melalui beberapa mekanisme yang mungkin disebabkan oleh pengaruh kafein terhadap peningkatan kadar epinefrin dalam plasma (Lane dkk., 2008), peningkatan kebutuhan energi basal, menstimulasi oksidasi lemak dan mobilisasi glikogen pada jaringan otot serta dapat merangsang pelepasan asam lemak bebas dari jaringan perifer (Tjekyan, 2007).

Beberapa penelitian menyatakan bahwa konsumsi kafein dapat meningkatkan kadar gula darah melalui beberapa mekanisme (Lane dkk., 2008; Tjekyan, 2007). Namun di sisi lain, terdapat beberapa penelitian yang menyatakan bahwa konsumsi kopi, yaitu minuman yang kandungan utamanya adalah kafein dapat menurunkan kadar gula darah (Arnlov, 2017; Akash dkk., 2012; Lane dkk., 2008). Oleh karena itu, penelitian ini bertujuan untuk mengetahui pengaruh pemberian kafein per oral terhadap kadar gula darah pada tikus normal dan hiperglikemia.

\section{BAHAN DAN METODE}

\section{Alat}

Alat yang digunakan pada penelitian ini adalah NESCO ${ }^{\circledR}$ MultiCheck, NESCO ${ }^{\circledR}$ MultiCheck Glucose strip test, kandang tikus, timbangan pengukur berat badan tikus, spuit, gunting, sonde lambung, timbangan digital.

Bahan

Digunakan streptozotocin $65 \mathrm{mg} / \mathrm{Kg} \mathrm{BB}$, kafein, dan tikus putih strain wistar.

\section{Metode}

Penelitian ini merupakan jenis penelitian eksperimental yang menggunakan pre test and posttest with control group design.

Populasi penelitian adalah tikus (Rattus novergicus) putih strain wistar jantan, sehat, umur 8 - 10 minggu, berat 110 - 160 gram yang diperoleh di Unit Hewan Coba Laboratorium Biokimia, Fakultas Kedokteran Universitas Airlangga. Total besar sampel adalah 36 ekor yang diambil dengan cara simple random sampling.

Terdapat 4 kelompok dengan randomisasi sederhana dengan rincian 2 kelompok kontrol dan 2 kelompok perlakuan. K1 adalah kelompok tikus hiperglikemia yang diberi perlakuan, K2 adalah kelompok tikus hiperglikemia kontrol, K3 adalah kelompok tikus normal yang diberi perlakuan dan K4 adalah kelompok tikus normal kontrol. Kelompok hiperglikemia adalah kelompok tikus yang di induksi dengan streptozotocin $65 \mathrm{mg} / \mathrm{Kg}$ BB pada awal percobaan. Perlakuan yang diberikan adalah dengan pemberian kafein per oral dosis 3,22 mg/200 gram $\mathrm{BB} /$ hari selama 3 hari pada kelompok perlakuan. Pengecekan kadar gula darah menggunakan alat glukometer dilakukan sebelum dan sesudah perlakuan.

Data dikumpulkan dan dianalisis secara statistik dengan uji normalitas dan uji homogenitas untuk memenuhi asumsi uji parametrik yaitu data berdistribusi normal dan homogen. Kemudian dilakukan uji paired t-test untuk mengetahui apakah terdapat perbedaan antara data pre test dan post test untuk kelompok kontrol dan eksperimen dan selanjutnya dilakukan uji independent $t$ untuk mengetahui apakah terdapat perbedaan rata-rata kelompok post test data kontrol dan post test data eksperimen. Untuk mengetahui besar efek pemberian variabel bebas terhadap sampel, dilakukan perhitungan menggunakan effect size.

\section{HASIL DAN PEMBAHASAN Deskripsi data}

Pengecekan kadar gula darah dilakukan sebelum dan setelah perlakuan, yaitu pemberian kafein secara peroral dengan dosis $3 \mathrm{mg} / 200 \mathrm{Kg} \mathrm{BB} /$ hari selama tiga hari. 
Tabel 1. Kadar gula darah hewan coba sebelum dan sesudah perlakuan (mg/dL)

\begin{tabular}{cccccccc}
\hline \begin{tabular}{c} 
K1 (Hiperglikemia- \\
\multicolumn{2}{c}{ Perlakuan) }
\end{tabular} & \multicolumn{2}{c}{$\begin{array}{c}\text { K2 (Hiperglikemia- } \\
\text { Kontrol) }\end{array}$} & \multicolumn{2}{c}{$\begin{array}{c}\text { K3 (Normal- } \\
\text { Perlakuan) }\end{array}$} & \multicolumn{2}{c}{$\begin{array}{c}\text { K4 (Normal- } \\
\text { Kontrol) }\end{array}$} \\
\hline \multicolumn{2}{r}{$\begin{array}{c}\text { Pre test } \\
\text { Post test }\end{array}$} & Pre test & Post test & Pre test & Post test & Pre test & Post test \\
\hline 483 & $>600$ & 392 & 402 & 102 & 143 & 113 & 130 \\
483 & $>600$ & 433 & 450 & 122 & 157 & 97 & 97 \\
385 & 557 & 366 & 400 & 104 & 141 & 107 & 107 \\
287 & 505 & 375 & 390 & 84 & 155 & 110 & 104 \\
505 & $>600$ & 391 & 360 & 122 & 155 & 122 & 107 \\
453 & 483 & 370 & 287 & 92 & 115 & 79 & 104 \\
420 & $>600$ & 455 & 453 & 105 & 110 & 92 & 99 \\
402 & $>600$ & 409 & 433 & 104 & 117 & 127 & 122 \\
380 & 596 & 453 & 445 & 84 & 136 & 105 & 101 \\
\hline
\end{tabular}

Tabel 2. Uji normalitas one-sample kolmogorov-smirnov test

\begin{tabular}{cccc}
\hline Kadar Gula & Kelompok Data & Kolmogorov-Smirnov Test & $p$-value \\
\hline \multirow{3}{*}{ Normal } & Pre test Kontrol (K4) & 0,437 & 0,991 \\
& Post test Kontrol (K4') & 0,930 & 0,353 \\
& Pre test Eksperimen (K3) & 0,588 & 0,880 \\
& Post test Eksperimen (K3') & 0,568 & 0,904 \\
\hline \multirow{3}{*}{ Hiperglikemia } & Pre test Kontrol (K2) & 0,602 & 0,862 \\
& Post test Kontrol (K2') & 0,562 & 0,910 \\
& Pre test Eksperimen (K1) & 0,472 & 0,979 \\
& Post test Eksperimen (K1') & 1,112 & 0,169 \\
\hline
\end{tabular}

\section{Analisis data}

\section{Pengujian asumsi}

Pengujian normalitas digunakan untuk mengetahui distribusi data dengan menetapkan $\alpha$ sebesar $1 \%$ dan menggunakan uji Kolmogorov-Smirnov.

Berdasarkan Tabel 2 diatas, dapat diketahui nilai p-value untuk masing-masing kelompok data pada kelompok kadar gula normal masing-masing lebih besar dari 0,001 (1\%). Sama halnya untuk kelompok data pada kelompok kadar gula hiperglikemia masingmasing lebih besar dari 0,001 (1\%). Sehingga dapat dikatakan bahwa data yang digunakan pada penelitian ini masing-masing berdistribusi normal.

Berdasarkan Tabel 3, dapat diketahui bahwa nilai p-value untuk data kontrol pada kadar gula normal (pre test dengan posttest kontrol) dan nilai $p$-value untuk data eksperimen masing-masing sebesar 0,428 dan 0,262 . Sedangkan $p$-value untuk data kontrol pada kadar gula hiperglikemi dan nilai $p$-value untuk data eksperimen masing-masing sebesar 0,479 dan 0,342. Sehingga dapat disimpulkan bahwa varians antara nilai pratest dengan nilai posttest pada masing-masing data homogen.
Uji homogenitas digunakan untuk mengetahui varians dari beberapa populasi sama atau tidak. Dengan menetapkan $\alpha$ sebesar $1 \%$ dan menggunakan uji Homogenity of variance diperoleh nilai $p$-value untuk masing-masing data sebagai berikut:

Tabel 3. Uji homogenitas

\begin{tabular}{ccc}
\hline Kadar Gula & Data & $p$-value \\
\hline \multirow{2}{*}{ Normal } & Kontrol & 0,428 \\
& Eksperimen & 0,262 \\
\hline \multirow{2}{*}{ Hiperglikemia } & Kontrol & 0,479 \\
& Eksperimen & 0,342 \\
\hline
\end{tabular}

\section{Pengaruh pemberian kafein terhadap kadar gula} darah

Uji paired t-test digunakan untuk mengetahui apakah terdapat perbedaan rata-rata suatu variabel pada waktu yang berbeda dengan syarat memenuhi asumsi normalitas dan homogenitas. normal dan hiperglikemia. Dengan menggunakan $\alpha=0,01$ diperoleh hasil analisis sebagai berikut. 


\section{Pengaruh pemberian kafein terhadap kadar gula darah}

Uji paired t-test digunakan untuk mengetahui apakah terdapat perbedaan rata-rata suatu variabel pada waktu yang berbeda dengan syarat memenuhi asumsi normalitas dan homogenitas. normal dan hiperglikemia. Dengan menggunakan $\alpha=0,01$ diperoleh hasil analisis sebagai berikut.

Tabel 4. Uji paired t-test

\begin{tabular}{ccccc}
\hline Kadar Gula & Kelompok & Data & $T$ & p-value \\
\hline \multirow{2}{*}{ Normal } & Kontrol & Pre test-Post test & $-0,512$ & 0,623 \\
& Eksperimen & Pre test-Post test & $-5,204$ & 0,001 \\
\hline \multirow{2}{*}{ Hiperglikemia } & Kontrol & Pre test-Post test & 0,0224 & 0,828 \\
& Eksperimen & Pre test-Post test & $-7,049$ & 0,000 \\
\hline
\end{tabular}

Berdasarkan Tabel 4 diatas, dapat diketahui nilai $p$-value yang kurang dari 0,05 pada uji tersebut terdapat pada kelompok eksperimen pada kadar gula normal dan hiperglikemia.

\section{Effect Size Kafein Terhadap Kadar Gula Darah Tikus Normal}

Uji independent $t$ harus dilakukan sebelum menghitung effect size. Pengujian ini dilakukan untuk mengetahui apakah terdapat perbedaan rata-rata kelompok post test data kontrol dan post test data eksperimen pada tikus berkadar gula normal. Dengan menggunakan $\alpha=0,05$ diperoleh hasil sebagai berikut:

Tabel 5. Independent $t$ kadar gula darah normal

\begin{tabular}{cccccc}
\hline Kadar Gula & Kelompok & Rata-rata & SD & $T$ & $p$-value \\
\hline \multirow{2}{*}{ Normal } & Kontrol & 107,889 & 10,982 & \multirow{2}{*}{4,011} & 0,001 \\
& Eksperimen & 136,556 & 18,413 & & \\
\hline
\end{tabular}

Berdasarkan Tabel 5 diketahui bahwa nilai ratarata kadar gula pada tikus normal kontrol sebesar 107,889, sedangkan rata-rata kadar gula pada tikus normal perlakuan sebesar 136,556. Nilai p-value yang diperoleh melalui uji independent $\mathrm{t}$ sebesar 0,001 atau lebih kecil dari 0,05. Sehingga dapat disimpulkan bahwa kafein berpengaruh signifikan terhadap kadar gula pada tikus normal. Selanjutnya penghitungan effect size kafein terhadap kadar gula pada tikus normal adalah sebagai berikut:

$$
\begin{gathered}
\mathrm{t}=4,011 \\
\mathrm{n}_{\mathrm{t}}=9 \\
\mathrm{n}_{\mathrm{c}}=9
\end{gathered}
$$

$$
d=4,011 \sqrt{\left(\frac{9+9}{9 \times 9}\right)\left(\frac{9+9}{9+9-2}\right)}=2,005
$$

Diperoleh effect size sebesar 2,005. Jika dilihat pada Tabel The interpretation of cohen's $d$ maka angka 2,005 berada pada presentase $81,1 \%$.

Effect size kafein terhadap kadar gula darah tikus hiperglikemia size kafein terhadap kadar gula pada tikus hiperglikemia

Uji independent $t$ harus dilakukan sebelum menghitung effect size. Pengujian independent $t$ dilakukan untuk mengetahui apakah terdapat perbedaan rata-rata kelompok post test data kontrol dan post test data eksperimen pada tikus hiperglikemia. Dengan menggunakan $\alpha=0,05$ diperoleh hasil pada Tabel 6 sebagai berikut: 
Tabel 6. Independent $t$ kadar gula darah hiperglikemia

\begin{tabular}{cccccc}
\hline Kadar Gula & Kelompok & Rata-rata & SD & $T$ & p-value \\
\hline Hiperglikemia & Kontrol & 402,222 & 53,446 & 7,172 & 0,000 \\
& Eksperimen & 571,222 & 46,267 & & \\
\hline
\end{tabular}

Berdasarkan Tabel 6 dapat diketahui bahwa nilai rata-rata kadar gula tikus hiperglikemia kontrol sebesar 402,222, sedangkan rata-rata kadar gula tikus hiperglikemia perlakuan sebesar 571,222. Nilai p- value yang diperoleh melalui uji independent $\mathrm{t}$ diketahui sebesar 0,000 atau lebih kecil dari 0,05. Sehingga dapat disimpulkan bahwa bahwa kafein berpengaruh signifikan terhadap kadar gula pada tikus hiperglikemia. Selanjutnya penghitungan effect size kafein terhadap kadar gula pada tikus hiperglikemia adalah sebagai berikut.

$$
\begin{aligned}
& \mathrm{t}=4,011 \\
& \mathrm{n}_{\mathrm{t}}=9 \\
& \mathrm{n}_{\mathrm{c}}=9 \\
& d=t \sqrt{\left(\frac{n_{t}+n_{c}}{n_{t} n_{c}}\right)\left(\frac{n_{t}+n_{c}}{n_{t}+n_{c}-2}\right)} \\
& d=7,172 \sqrt{\left(\frac{9+9}{9 \times 9}\right)\left(\frac{9+9}{9+9-2}\right)}=3,586
\end{aligned}
$$

Diperoleh effect size sebesar 3,586. Jika dilihat pada Tabel The interpretation of cohen's $d$ maka angka 3,586 berada pada presentase $97.7 \%$.

Pemeriksaan kadar gula darah pada tikus yang menggunakan glukometer dilakukan sebelum perlakuan dan setelah perlakuan, yaitu pemberian kafein dosis 3,22 mg/200 Kg BB/hari secara per oral. Kelompok hiperglikemia diinduksi enggunakan streptozotocin secara single dose dengan dosis $65 \mathrm{mg} / \mathrm{Kg}$ BB dan kadar gula darah diukur tiga hari setelah induksi. Hal ini berdasarkan studi yang mengatakan bahwa setelah tiga hari, streptozotocin membuat pancreas membengkak dan sel islet beta pancreas mengalami degenerasi (Akbarzadeh, 2017).

Penelitian ini dilakukan selama 3 hari berdasarkan penelitian sebelumnya yang mengatakan bahwa selama tiga hari kafein dapat memberikan efek terhadap tikus yang telah terinduksi oleh streptozotocin sebelumnya (Kagami, 2017).

Hasil dari penelitian ini setelah dilakukan uji paired t-test menunjukkan bahwa pemberian kafein per oral dapat menaikkan kadar gula darah secara signifikan pada tikus yang memiliki kadar gula normal maupun kadar gula hiperglikemia. Selanjutnya dengan menggunakan uji Effect Size didapatkan pengaruh kafein dalam menaikkan kadar gula darah pada tikus yang memiliki kadar gula normal sebesar $81,1 \%$ dan pengaruh kafein dalam menaikkan kadar gula darah pada tikus hiperglikemia sebesar 97,7\%.

Pengaruh pemberian kafein terhadap kadar gula darah masih menjadi diskusi para peneliti apakah menaikkan atau menurunkan kadar gula darah. Efek kafein terhadap toleransi glukosa masih belum jelas (Urzua dkk., 2012). Menurut Akash dkk (2012), kopi yang merupakan sumber utama dari kafein dapat menunjukkan perlindungan terhadap diabetes (Akash dkk., 2012; Van dkk., 2004). Namun ternyata, selain mengandung kafein, kopi juga mengandung asam klorogenik yang merupakan suatu polifenol. Kadar asam klorogenik pada kopi cukup besar yaitu pada $200 \mathrm{~mL}$ kopi adalah sekitar 70 - $350 \mathrm{mg}$. Polifenol adalah antioksidan yang memiliki fungsi mencegah berbagai penyakit seperti sirosis hari dan diabetes mellitus tipe 2. Senyawa polifenol dapat memperlambat pengeluaran glukosa ke peredaran darah setelah makan (National Center for Biotechnology Information, 2018).

Terdapat beberapa fungsi kafein pada tubuh. Kafein adalah suatu antagonis dari reseptor adenosin. Selain itu, kafein juga merupakan inhibitor enzim fosfodiesterase, memicu pengeluaran kalsium intraseluler ke ekstraseluler dan antagonis dari reseptor benzodiazepine. Kafein juga memicu pengeluaran dari norepinefrin, dopamin, asetilkolin, serotonin, glutamat, GABA dan neuropeptida yang lain. Sebagai antagonis reseptor adenosin, kafein menghambat adenosin untuk menempel ke reseptornya secara non selektif, yaitu menghambat reseptor A1, A2A, A3, A2B (Ribeiro \& Sebastiao, 2010).

Adenosin adalah nukleosida purin endogen yang berasal dari seluruh jaringan meliputi hepar, pankreas, otot dan lemak dalam keadaan stress. Adenosin berasal dari pemecahan ATP di ruang ekstraseluler dengan bantuan 2 enzim endonukleotidase, yaitu nukleosid trifosfat difosforilase 1 (ENTPD1) dan ecto 5 nukleotidase (NT5E). Selain itu adenosin juga bisa berasal dari ATP intrasel dengan bantuan 2 enzim 
yaitu ENT1 dan ENT2. Peran dari adenosin pada homeostasis glukosa melalui reseptornya adalah mengatur proses sekresi insulin, rilis dan klirens glukosa, glikogenolisis dan glikogenesis. Studi membuktikan bahwa adenosin dapat memicu sekresi insulin dan menurunkan produksi glukosa. Selain itu, adenosin juga berperan dalam metabolisme lipid dan kolesterol (Koupenova \& Ravid, 2017).

Reseptor adenosin, terutama A1, berperan dalam mekanisme homeostasis glukosa. Apabila teraktivasi, reseptor ini dapat memodulasi peran insulin dalam transport glukosa ke dalam otot melalui glukosa transporter 4 atau GLUT 4. Reseptor adenosin A1 menstimulasi transport glukosa oleh insulin terutama pada otot skeletal yang berkontraksi. Lebih jauh lagi, reseptor adenosin A1 dapat memfasilitasi ambilan glukosa yang diperantarai oleh insulin ke adiposit dan myocardium. Kafein menghambat kontraksi otot skeletal sebesar 30 - 50\% (Dhalla dkk., 2017).

Otot skeletal adalah tempat utama untuk penyimpanan glukosa selain hepar. Saat kondisi istirahat atau basal, ambilan glukosa rendah. Namun, saat otot berkontraksi, kecepatan ambilan glukosa akan meningkat, apalagi ketika kadar insulin tinggi, maka ambilan glukosa akan lebih meningkat lagi. Ketika terjadi kontraksi dan paparan insulin, ambilan glukosa naik daripada hanya terjadi kontraksi saja maupun paparan insulin saja, hal ini merupakan fenomena aditif sinergis. Insulin dan kontraksi secara independendapat memicu transport glukosa melalui peningkatan jumlah transporter glukosa di sarkolema secara aktif maupun peningkatan aktivitas intrinsik transporter (Thong \& Laily, 2017).

Saat otot berkontraksi dengan intensitas yang tinggi, otot akan menggunakan ATP sebagai sumber energi. ATP akan terdegradasi menjadi AMP dan adenosin dengan bantuan enzim adenilat kinase dan enzim 5'nukleotidase. Di sarkoplasma, adenosin yang terbentuk akan keluar ke intersisial dan teraktivasi menjadi hormon lokal dan menempel di reseptor adenosin pada sel tertentu. Tanda kemerahan atau hiperemi pada kulit ketika otot berkontraksi merupakan salah satu kontribusi dari melekatnya adenosin pada reseptor adenosin di pembuluh darah sehingga akan mengalami vasodilatasi. Beberapa penelitian menyebutkan bahwa selain berkontribusi terhadap regulasi vasomotor, reseptor adenosin juga berperan dalam regulasi insulin terutama di otot skeletal (Vergauwen dkk., 2017).

Pada penderita diabetes mellitus, kafein dapat menyebabkan hiperglikemia. Selain mempengaruhi ambilan glukosa di otot skeletal dan peningkatan lipolisis, kafein juga dapat memicu hormon yang berperan sebagai kounterregulasi glukosa seperti epinefrin, yang menurunkan ekskresi glukosa, sehingga kadar glukosa dalam darah tinggi. Epinefrin adalah suatu hormon yang berperan dalam aktivitasi sistem simpatik. Seperti yang diketahui bahwa insulin adalah hormon penting yang berperan dalam meregulasi kadar gula darah agar tidak meningkat. Insulin dihasilkan oleh sel beta pankreas. Stimulasi simpatis dari epinefrin dapat menurunkan aktivitas sel beta pankreas sehingga produksi insulin akan menurun dan kadar gula darah akan naik (Zaharieva \& Riddell, 2013).

\section{KESIMPULAN}

Pemberian kafein per oral dapat meningkatkan kadar gula darah tikus hiperglikemia sebesar $97,7 \%$ dan tikus normal sebesar $81,1 \%$.

Perlu dilakukan penelitian lebih lanjut menggunakan kafein per oral dengan dosis bertingkat untuk mengetahui pengaruh kafein per oral terhadap kadar gula darah dengan dosis yang bervariasi, jangka waktu lebih lama guna mengetahui efek kronis kafein per oral terhadap kadar gula darah, penilaian kenaikan kadar gula darah secara lebih teliti dengan menggunakan metode yang lebih akurat seperti pemeriksaan laboratorium serta diharapkan hasil penelitian ini dapat memberikan masukan untuk mempertimbangkan pengaruh pemberian kafein terhadap kadar gula darah.

\section{DAFTAR PUSTAKA}

Akash, M., Rehman, K. \& Chen, S. (2014). Effects of Coffee on Type 2 Diabetes Mellitus by PubMed NCBI. Nutrition; 30; 755-763.

Akbarzadeh, A. (2017). Induction of Diabetes by Streptozotocin in Rats. Indian Journal of Clinical Biochemistry; 22; 60-64.

Arnlov, Je. (2017). Coffee Consumption and Insulin Sensitivity. The Journal of the American Medical Association; 291; 1199-1201.

Dhalla, A. K., Chisholm, J. W. \& Reaven, G. M. (2017). A1 Adenosine Receptor: Role in Diabetes and Obesity. Handbook of experimental pharmacology; 193; 271-295.

Kagami, K. E. (2017). Protective Effect of Caffeine on Streptozotocin-Induced Beta-Cell Damage in Rats. Journal of Pharmacy and Pharmacology; 60; 1161-1165. 
Koupenova, M. \& Ravid, K. (2017). Adenosine, Adenosine Receptors and Their Role in Glucose Homeostasis and Lipid Metabolism. https://www.ncbi.nlm.nih.gov/pmc/articles/PMc 3849123/. Accessed: 30 September 2017.

Lane, J., Feinglos, M. \& Surwit, R. (2008). Caffeine Increases Ambulatory Glucose and Postprandial Responses in Coffee Drinkers with Type 2 Diabetes. Diabetes Care; 31; 221-222.

Mayo Clinic. (2018). Caffeine Content for Coffee, Tea, Soda and more. https://www.mayoclinic.org/healthylifestyle/nutr ition-and-healthy-eating/in-depth/caffeine/art20049372. Accessed: 9 Februari 2018.

National Center for Biotechnology Information. (2018). PubChem Compound Database. https://pubchem.ncbi.nlm.nih.gov/compound/17 94427. Accessed: 9 Februari 2018.

Ribeiro, J. \& Sebastiao, A. (2010). Caffeine and Adenosine. Journal of Alzheimer's Disease; 20; S3-15.

Thong, F. S. \& Laily, J. S. (2017). Activation of the A1 Adenosine Receptor Increases InsulinStimulated Glucose Transport in Isolated Rat Soleus Muscle. Applied Physiology, Nutrition, and Metabolism; 32; 701-10.
Tjekyan, R. (2007). Risiko Penyakit Diabetes Mellitus Tipe 2 di Kalangan Peminum Kopi di Kotamadya Palembang Tahun 2006-2007. Makara, kesehatan; 11; 54-60.

Urzua, Z., Trujillo, X., Trujillo, Hernandez, B., Rios, S. M., Onetti, C., Ortiz \& Mesina. (2012). Effects of Chronic Caffeine Administration on Blood Glucose Levels and on Glucose Tolerance in Healthy and Diabetic rats. Journal of International Medical Research; 40; 2220-2230.

Van, D. R., Pasman, W. \& Verhoef, P. (2004). Effects of Coffee Consumption on Fasting Blood Glucose and Insulin Concentrations: Randomized Controlled Trials in Healthy Volunteers. Diabetes Care; 27; 2990-2992.

Vergauwen, L., Hespel, P. \& Richter, E. A. (2017). Adenosine Receptors Mediate Synergistic Stimulation of Glucose Uptake and Transport by Insulin and by Contractions in Rat Skeletal Muscle. The Journal of Clinical Investigation; 93; 974-981.

Zaharieva, D. \& Riddell, M. (2013). Caffeine and Glucose Homeostasis during Rest and Exercise in Diabetes Mellitus. Applied Physiology, Nutrition, and Metabolism; 38; 813-82. 